\title{
テラヘルツテクノロジーの将来展望
}

\author{
斗内 政吉 \\ 大阪大学レーザーエネルギー学研究センター（テ565-0871 大阪府吹田市山田丘2-6）
}

\section{Future Prospect of Terahertz Technology}

\author{
Masayoshi TONOUCHI \\ Institute of Laser Engineering, Osaka University, 2-6 Yamadaoka, Suita, Osaka 565-0871
}

(Received June 13, 2005)

\begin{abstract}
Terahertz (THz) technology is becoming increasingly important in both science and technology. THz timedomain spectroscopy (THz-TDS) and THz quantum cascade lasers (QCLs) provide a powerful tool to explore the nature of various kinds of materials for a low energy excitation and ultrafast dynamics; the THz imaging is expected to be applicable to security, factory testing and so on. Thus THz-TDS and QCLs have triggered the research field of THz-technology-based basic research and application research. In addition to those activities, the development of ultrafast devices and logic circuits in the fields of $\mathrm{THz}$ photonics and $\mathrm{THz}$ electronics has accelerated the growth of the $\mathrm{THz}$ research field such as $\mathrm{THz}$ wireless communication, $\mathrm{THz}$ network system, ultrafast ADCs and so on. This paper reviews the future prospect of such THz-technology-based research fields.
\end{abstract}

Key Words: Tterahertz technology, Terahertz waves, Terahertz photonics, Terahertz electronics

1.はじめに

光と電波の間には，これまで利用が困難であった未開 拓領域“テラヘルツ $(\mathrm{THz})$ ”带 $\left(1 \mathrm{THz}=10^{12} \mathrm{~Hz}\right)$ が存在す る。光通信で利用される波長 $1.55 \mu \mathrm{m}$ は，周波数でいうと 約 $200 \mathrm{THz}$ に対応し，また，10,000 THzを超える光技術 は，最先端の半導体ナノ加工技術，30 nm領域を支えてい る. 一方, $1 \mathrm{GHz}(0.001 \mathrm{THz})$ 近傍は, 携帯電話などの無線 通信として，60〜80 GHzは，車載用ミリ波レーダとし て, また, 数 $\mathrm{GHz} て ゙$ 動作するCPUも広く普及しており, 約 $100 \mathrm{GHz}$ を上限として, 電波応用・情報処理技術など, 様々に利用されている。その様な周波数利用の観点か ら，100 GHzから $100 \mathrm{THz}$ にあテラヘルツ带は，電子デ バイスの動作上限周波数に近く，良質の信号源や光源が なく，また，水の吸収が大きく影響するなど，利用に大 きな障害があり，電波天文など宇宙の観測，フーリエ． ラマン分光など，特殊な計測・分析分野に限られてい た。しかし今，科学技術の発展に伴い，テラヘルツ带利 用への道が開かれつつあり，次世代の産業に大きな役割 を果たすことが期待されている。

テラヘルツ技術は，新しいセンシング機能を提供し， 工業・医療・バイオ・農業・セキュリテイなど様々な分 野における応用が見込まれている。また，情報通信分野 においては，利用電磁波のますますの高周波化が進んで おり，数百 $\mathrm{GHz}$ の無線通信が実現される時期も遠くはな
い.ナノ技術の発展に伴って，テラヘルツ動作を目指す 半導体デバイス, 動作周波数 $200 \mathrm{GHz}$ 目指寸超伝導単一 磁束量子 (SFQ) 論理回路の開発も急速に進展し, 高速信号 処理技術などテラヘルッ帯信号処理が可能になりつつあ る。テラヘルツ技術は, そのような次世代の機能センシ ング・情報通信・エレクトロニクスの基盤となるべき科 学技術分野を切り開くとともに, 基礎科学の分野におい ても不可欠な分野である.テラヘルッ帯には, 固体中の 光学フォノン散乱・プラズマ周波数, イオン分極・配向 分極などの誘電性, 超伝導体エネルギーギャップ, 分 子・固体中の各種振動/分子間相互作用など興味深い物性 が存在し，また，生体温度領域にもあることから，バイ オ・生体活動を科学する重要なプラットフォームであ り，更に，テラヘルツ波を観測することで宇宙誕生の鍵 を解く情報収集が期待されるなど，サイエンスの宝庫で もある。1893年に発刊された米国物理学会誌“The Physical Review”第1巻第1号第1ページは，赤外分光に関する論文 から始まっており, 古くから光と電波の境界領域は研究 者の興味を引いてきた1). 今，100年の時を超え，テラへ ルツ研究は新たなるステージへと発展を始めている.

以上のような背景において, 2004年度, 総務省からの 委託を受け，(財)テレコム先端技術研究支援センター (SCAT)がテラヘルッテクノロジー動向調査委員会を設置 し，同調査を実施した。本報では，その“テラヘルッテク ノロジー動向調査報告書” 2$)$ のから，テラヘルツ技術を 
融合させることで切り拓かれる新しい応用分野や研究課 題について簡単に紹介する。

\section{2. テラヘルツテクノロジーの新展開}

テラヘルツに関する研究は様々な分野で行われてき た．大きく分けると3つの分野に整理できる．まず，現在 注目される“テラヘルッ”を率引しているのが，テラヘルッ 波(Terahertz Waves)，また，次世代の情報通信の鍵を握る のがテラヘルッフォトニクス(Terahertz Photonics), そして あらゆる基盤となるのがテラヘルツエレクトロニクス (Terahertz Electronics) 分野である。その対象となる応用分 野も情報通信，デジタルエレクトロニクス，セキュリ ティ，固体物性，バイオ，生体分析など多岐にわたって いる。それらが，科学技術の進展によりテラヘルツ带に おいて共存・融合を始めた今まさに“テラヘルツテクノ ロジー”を基盤とした新研究開発領域を創成し，総合的な 融合産業応用分野の開拓を目指すことを提案する. (Fig. 1)

テラヘルツ波研究分野においては，2つの重要な進展が あった，第一は，時間領域テラヘルツ電磁波発生・検出 手法の開発である。これは，フェムト秒レーザーを用い ることで, 超高速電流変調を実現し, 超高速光スイッチ を用いて，超短電磁波パルスの発生と時間遅延を用いた その電磁波波形の時間領域検出を実現したもので，現在 ではそのフーリエ成分が数 $\mathrm{GHz}$ から百 $\mathrm{THz}$ を超える超ブ ロードバンドテラヘルツ波が実現されており, 様々な分 析応用やそのシステム開発が行われている3-5). 第二の工 ポックメイキングは，量子カスケードレーザー(QCL) 6,7) である。ナノ技術の進展により，高精度に制御された半 導体量子井戸構造の作製が可能となった。レーザー発振 は，井戸型構造におけるサブバンド間遷移を利用したも ので，現在までに2.1 THzまでの発振が確認され，QCLを 用いた分光研究なども始まっている.

テラヘルッフォトニクス研究分野では, 光・電磁波変 換の研究が急速に進展し，フォトミキシング技術を用い て, 高出力のテラヘルツ波の発生が可能となっている8). また, 現在, 波長多重技術で行われている光通信におい て, 将来の大容量化を目指し, ソリトン通信などの研究 開発も進んでおり，1チャネルあたりサブテラビットの情 報伝達が可能となっている。これらは, テラヘルツ技術 が，情報通信技術にブレークスルーを与え，新しい応用

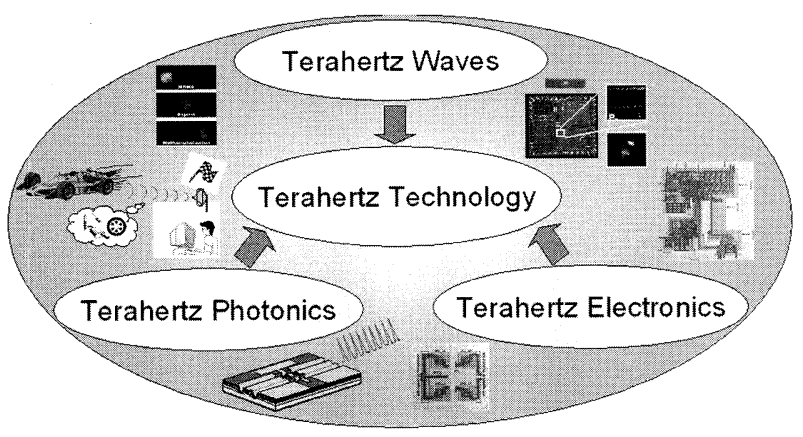

Fig. 1 Concept to form $\mathrm{THz}$ technology research field.
展開も含めて大きな進展をもたらすことを示している. テラヘルツエレクトロニクス研究分野では，超高速半導体 を用いたHEMTの最大発振周波数が $0.5 \mathrm{THz}$ 超え，また， 集積化により超高速 $\mathrm{AD}$ 変換器の開発も進んでいる た, SFQ論理回路の研究では, 動作周波数 $20 \mathrm{GHz}$ のマイク ロプロセッサが，既に実現されており10)，まさに，テラ ヘルツデジタル信号処理技術を利用できる環境が整いつ つある。

これらの研究が個々に進めてきた研究開発を統合的に 推進することで，研究開発を更に加速できるとともに， 新しい応用が切り開かれることが期待される．本テラへ ルツテクノロジーが目指す新産業展開の概念をFig. 2にま とめている。

\section{3. テラヘルツ技術が切り拓く新しい応用分野像}

\section{1 応用が見込まれる分野}

テラヘルツテクノロジーが切り拓く応用は, 主要3分 野，テラヘルツ波・テラヘルッフォトニクス・テラヘル ツエレクトロニクスの融合により，情報通信・生命・医 療・安全・健康・産業・環境・宇宙・科学など幅広い展 開が期待され，主な応用分野の観点からは，情報通信 (ICT) 分野とセンシング分野に大別できる. ICT分野で は，今後ますます発展が要望さるユビキタスネットワー ク社会における主要技術として，不可欠な存在となるこ とが期待される。センシング分野では，生体・高分子 . 電子材料など様々な物質の分光分析，ならびにイメージ ング技術と組み合せた医療診断・隠匿物検査・バイオメ トリクスなどへの応用が研究されている．以下それぞれ の分野における応用イメージを紹介する。

\section{2 テラヘルッICT分野}

より高速で，より大容量で，より自由な情報通信環境 実現に向けて多くの努力がなされている. 光通信の分野 では，10 GbpsのEthernetが有線系LANとして普及が始まっ ており, それらの進展に伴って, 基幹ネットワークで は, 毎秒数百Gbpの伝送量実現を目指して, 開発が進んで いる. 近い将来, 基幹ネットワークノードやサーバーに 扮ける大容量情報処理が不可欠であり，そのためにはテ

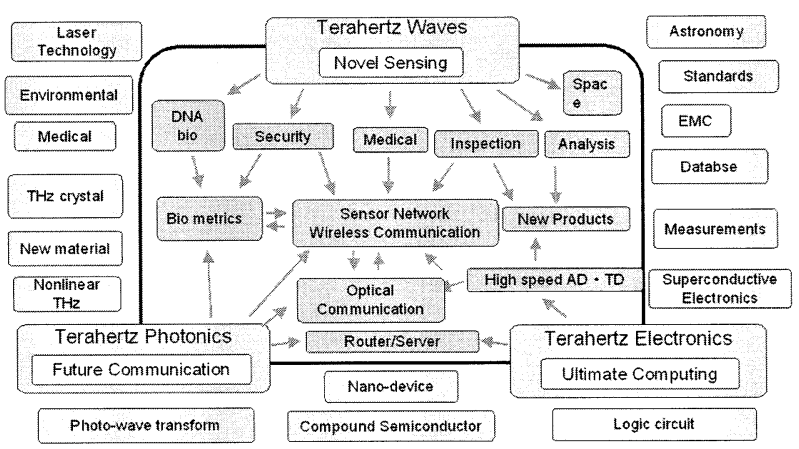

Fig. 2 Basic and application research fields due to the unification of $\mathrm{THz}$ waves, $\mathrm{THz}$ photonics, and $\mathrm{THz}$ electronics. 


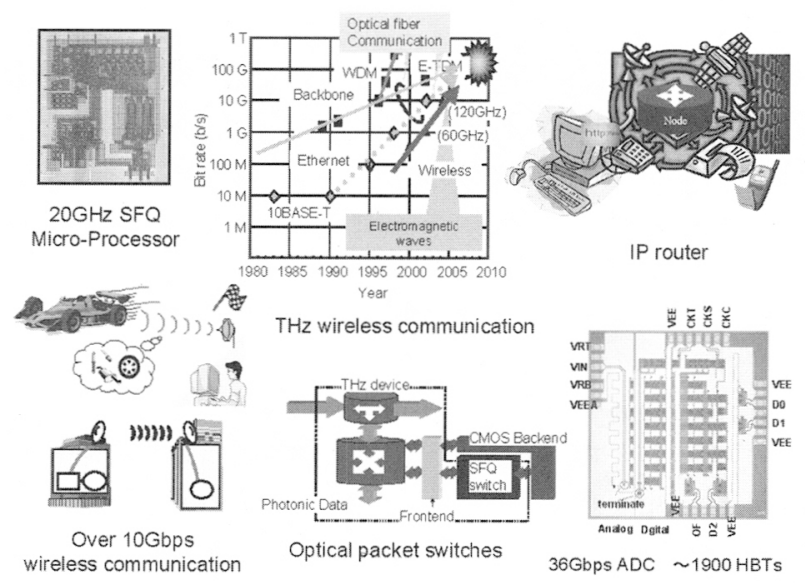

Fig. 3 Application images in the field of Information Communication Technology (ICT).

ラヘルツデバイス・集積回路の実現が重要な鍵を握る (Fig. 3). 現在では, その様な開発に向けて, 化合物半導体集積 回路による高速ADCや，SFQ回路による $40 \mathrm{GHz} \times 4=160$ Gbpsの光パケットスイッチ11)の開発が進められている.

一方, 無線LANはUWB (Ultra-Wide Band) や60 GHz無線 などにより $1 \mathrm{Gbps}$ 通信速度が実現されようとしており， $10 \mathrm{Gbps}$ 無線開発に向けた研究開発も開始されている. 将 来, 光ファイバ基幹ネットワークと無線通信システムが シームレスに連結されれば，大きな応用分野を開拓する ものと期待される. 例えば, F1レーシングカーとピット をつなぐ大容量・超高速デー夕通信，ファイバ敷設が困 難なビル間通信, 災害時の移動大容量無線などの実用化 が望まれる。現在までに，NTTの永妻らは，UTC-PDと フォトミキシング技術を用いて, $125 \mathrm{GHz}(10 \mathrm{Gbps})$ 無線 のフィールド実験を始めており, $10 \mathrm{Gbps} の$ 無線開発を進 めている。テラヘルッ無線において問題となるのが，水 蒸気に上る電磁波吸収である. Fig. 4にテラヘルッ電磁波 の水による減衰量を示す。屋外の短距離の無線では, 300 GHz程度までが現実的な無線通信带であり，40 Gbps程度 までは実現される可能性が高い。一方, 屋内の短距無線 等では，0.9 THz带まで利用可能範囲が広がる可能性があ る.

\section{3 センシング分野}

テラヘルツ波は, 様々な物質を透過し, X線・レーザー 光などと比較して安全であり, 物質固有の透過・吸収・ 反射特性(指紋スペクトル)を示すなど，様々な利点を有し ている．特に，テラヘルツ带時間領域分光法(THz-TDS) の実現により，テラヘルツ帯における複素屈折率・複素 誘電率・複素導電率などが容易に計測・評価できるよう になり，様々な物質のテラヘルツ带固有の物性を明らか にする手段が，大きなエポックメイキングをもたらし た。

電子材料のテラヘルツ帯における物性を明らかにするこ とは，電子デバイスの高周波動作極限を明らかにし，高 分子における分子間相互作用や水素結合の振る舞いなど も探索できる。医薬品に扔ける結晶多形評価の可能性も

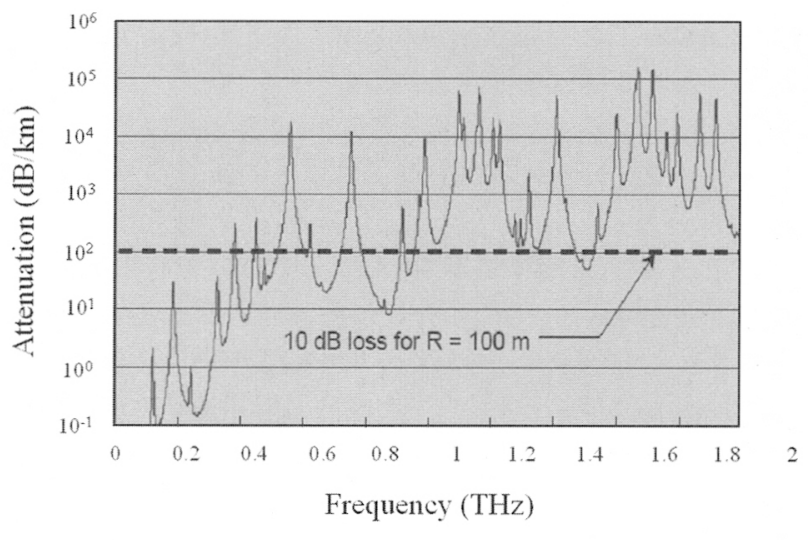

Fig. 4 Electromagnetic wave attenuation due to atmospheric absorption as a function of frequency. $\mathrm{H}_{2} \mathrm{O}, \mathrm{CO}_{2}$, $\mathrm{O}_{3}, \mathrm{~N}_{2} \mathrm{O}, \mathrm{CO}, \mathrm{CH}_{4}$, and $\mathrm{O}_{2}$ are taken into account in the 1976 U.S. standard atmospheric model @ sea level at a temperature of $288 \mathrm{~K}$, a pressure of $1 \mathrm{~atm}$, and a relative humidity of $55 \%$.
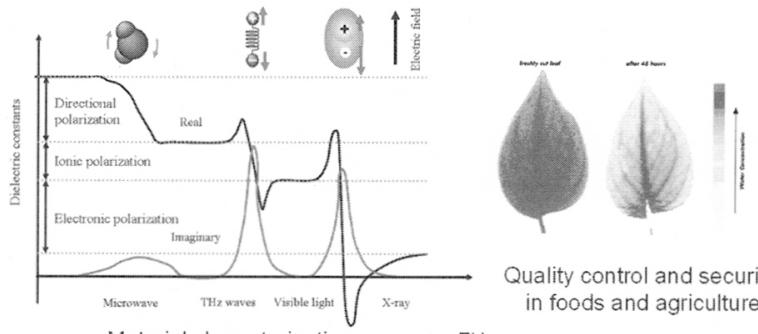

Quality control and security in foods and agriculture

Material characterization

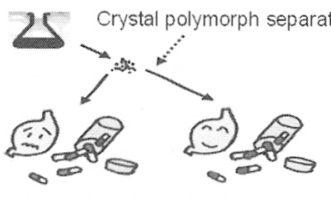

Control of drugs and medicines

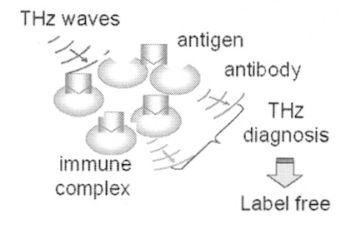

DNA analysis and Immune assay

Fig. 5 Application images in the field of $\mathrm{THz}$ spectroscopy.
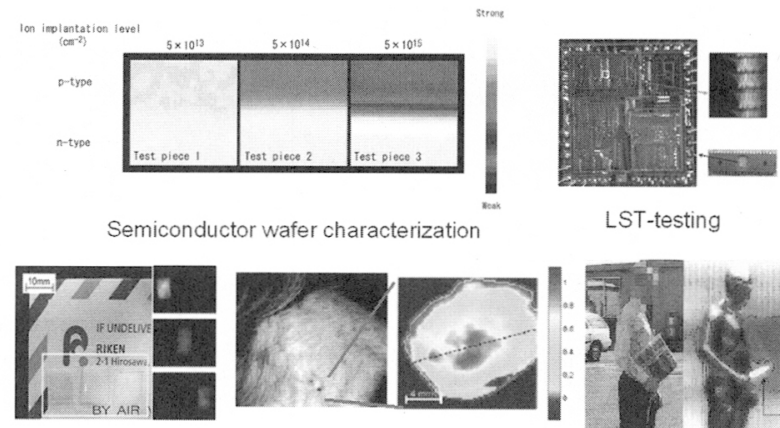

Hidden narcotics in mails

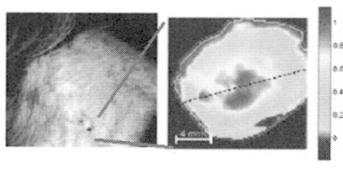

Skin cancer

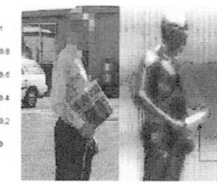

Concealed weapon

Fig. 6 Application images in the field of THz imaging spectroscopy.

指摘されており，その応用も期待されている。テラヘル ツ電磁波は, 水の吸収係数が大きく, その点から水の分 析や, 食品検査・管理手法としても期待される。また, テラヘルツ波を用いた光源抗体反応分析など新しい展開 も期待される (Fig. 5).

テラヘルツ波のもう一つの大きな特徴に, ビームとし 
ての取扱が容易であり，イメージング技術への応用が期 待されている点がある. M. Nussらが葉の水分分布イメー ジングを報告して以来，様々な試みがなされてきた。深 澤らは，THz-TDSによる半導体評価を可視化すること で，半導体ウェファーの評価に応用できることを示し た。また，川瀬らは，テラヘルッ分光による封筒内の禁 止薬物検査技術を開発し，欧州Star-Tigerチームは94 GHz パッシブカメラを開発し，隠匿物検査への応用を勧めて おり，テラヘルツ技術の安全安心社会への貢献が期待さ れている (Fig. 6)

テラビュー社を中心とした欧州プロジェクトでは，皮 膚がん検査などへの応用を進めており，また，日本固有 の応用として，テラヘルツ放射顕微鏡のLSI故障箕所検査 器機開発も進められており，テラヘルッイメージングの 幅広い応用が期待さている。

以上の応用研究に先立ち，古くからテラヘルツ研究を 牽引してきた分野として，宇宙・天文研究に打けるテラ ヘルツ技術がある。ALMA計画におけるテラヘルツ検出 器の開発は，世界的課題であり，着々と進められてお り，SMILESプロジェクトにおける衛星からのテラヘルツ 帯地球環境計測，ならびにASTRO-Fにおけるテラヘルッ イメージングアレーの開発など，大きなプロジェクトが 推進されている.

このようなセンシング応用に加えて，テラヘルツICTと の融合による新しい研究開発分野の創成も期待される. センシングと無線を組み合せたバイオメトリクス技術 や，センサネットワークの新しい構築など分野融合によ るシナジー効果も期待されている。

\section{4. 取り組むべき課題}

テラヘルツ産業を展開するに当たっては，様々な研究 課題が存在する。一例として，周波数と各種デバイスの 出力をまとめたものをFig. 7に示す。電気的発生では, 低 周波から高周波に向かって周波数の-2乗に比例して減少 し，光デバイスでは，高周波から低周波に向かって同様
に，周波数の2乗に比例して減少しており，特に0.5-30 THz帯域の高周波デバイスの開発が重要である。一方，テ ラヘルッ帯の計測機器の開発は，国内ではほとんど実施 されていないことから，テラヘルッ工学の発展には，計 測機器開発への投資が欠かせない。現在，アジレントテ クノロジーは，250 GHz帯のネットワークアナライザーの 販売を計画し， $500 \mathrm{GHz}$ 帯の開発も進めていることから， 国内における早期の研究開発の推進が望まれる。また, 通信応用やセンシング・セキュリティ応用にはテラヘル ツ電磁環境両立性 (EMC) 研究や標準化が不可欠であり, 早期の着手が望まれる。更に，テラヘルツ帯における分 子間相互作用など，これまで明らかにされていない物理 現象に関する情報が秘められており，応用展開に向けて 様々な物質のテラヘルツ物性データベースを構築するこ とも必要不可欠である。その他，重要な課題としては， 高感度テラヘルツ検出デバイス・テラヘルッカメラなど の開発，量子カスケードレーザーのチューナブル化・高 出力化・低しきい值化・高温動作化, 集積回路の高密 度・低消費電力化，などが挙げられる。各応用分野にお ける重要課題の具体例をTable 1に紹介する。これらを推進

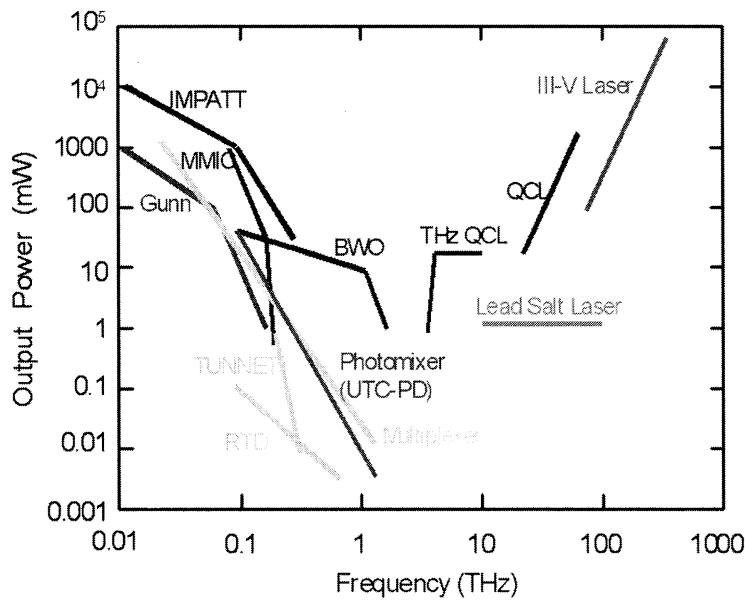

Fig. 7 Typical CW output power from various devices as a function of frequency.

Table 1 Research and development targets for $\mathrm{THz}$ application.

\begin{tabular}{|c|c|}
\hline Field & Task and Challenge \\
\hline $\begin{array}{l}\text { Information- } \\
\text { communication }\end{array}$ & $\begin{array}{l}\text { Tbps communication, THz wireless communication, Ultrafast data processing } \\
\text { systems, THz IT devices, THz measurement equipments, THz sensor and } \\
\text { Camera, THz sensor network, Biometrics, satellite communication, EMC }\end{array}$ \\
\hline $\begin{array}{l}\text { Bio/Medical/ } \\
\text { Medicine } \\
\text { /Infrastructure }\end{array}$ & $\begin{array}{l}\text { Cancer diagnosis, Immune array, Crystal polymorph separation, Diagnosis } \\
\text { measurement systems, Data-base, Bio molecular, On-site THz imaging system, } \\
\text { Bio EMC, FEL for medical service }\end{array}$ \\
\hline $\begin{array}{l}\text { Security } \\
\text { /Environment } \\
\text { /Infrastructure }\end{array}$ & $\begin{array}{l}\text { Inspection system for hazardous materials/prohibited drugs, Data-base of } \\
\text { hazardous materials/prohibited drugs, THz sensor and Camera, Environmental } \\
\text { monitoring system and data-base, Traffic and road monitoring systems, disaster } \\
\text { wireless communication, Gas and environmental diagnosis by QCL }\end{array}$ \\
\hline $\begin{array}{l}\text { Industry } \\
\text { /Standards }\end{array}$ & $\begin{array}{l}\text { THz-TDS/imaging system for industrial applications, Evaluation systems for } \\
\text { semiconductor materials, nano materials, electronic materials and others, THz } \\
\text { sensor and Camera, LSI-testing system, Monitoring, controlling and security } \\
\text { handling systems for foods and agriculture, Data-base for foods and agricultural } \\
\text { applications, Power, frequency and other THz standard system, EMC }\end{array}$ \\
\hline $\begin{array}{l}\text { Basic science } \\
\text { /Astronomy }\end{array}$ & $\begin{array}{l}\text { Functional THz-TDS/Imaging systems, THz emitting and controlling devices, } \\
\text { Quantum-limit THz detectors, THz-FEL, THz local oscillators, Biomolecular } \\
\text { structure analysis, data-base, other exploratory research }\end{array}$ \\
\hline
\end{tabular}


するにあたり，テラヘルツ研究分野は未成熟な分野でも あり，探索的・挑戦的要素も多く含むことから，基礎・ 基盤技術育成と応用分野開拓のため，産学官が協調して 研究開発プロジェクトを進めることが重要である。

\section{5. まとめ}

テラヘルツテクノロジーの新しい枠組みとそれに基づ く展望を紹介した。テラヘルツ波工学，テラヘルツフォ トニクス，テラヘルッエレクトロニクスの3分野が融合す ることによる, 情報通信 ·生命・医療・安全・健康 · 産 業・環境・宇宙・科学など幅広い分野での応用の可能性 を紹介した。応用実現に向けた課題の解決にあたり, 分 野にとらわれないボーダレスな取組みが必要であること から，各省庁の強い連携のもと，効果的な産学官協調に よる研究開発プロジェクトが推進されることを強く希望 するものである。

\section{謝 辞}

本解説は，テラヘルツ動向調査委員会が取り䌆めた調 査報告書から概要を抜粋したのももので，60名を超える 調査委員会メンバー，(財)テレコム先端技術研究支援セン
ター $(\mathrm{SCAT})$ の皆様，ならびに総務省情報通信政策局技術 政策課・研究推進室の方々に，心から感謝したします。

\section{参考文献}

1) E. F. Nicols: Phys. Rev. 1 (1893) 1.

2) テラヘルッテクノロジー動向調査報告書“未来を拓くテラへ ルツ技術”，テラヘルツテクノロジー動向調査委員会/財団法 人テレコム先端技術研究支援センター(2005年3月).

3) B. Ferguson and X. -C. Zhang: Review Article Nature Materials 1 (2002) 26.

4) D. Mittleman (ed.): Sensing with Terahertz Radiation (Springer, Berlin 2003).

5) K. Sakai (ed.): Terahertz Optoelectronics (Springer, Berlin 2005).

6) J. Faist, F. Capasso, D. L. Sivco, C. Sirtori, A. L. Hutchinson, and A. Y. Cho: Science 264 (1994) 477.

7) Q. Hu, B. S.Williams, S. Kumar, H. Callebaut, S. Kohen, and J. L Reno: Semicond. Sci. Technol. 20 (2005) S228.

8) F. Nakajima, T. Furuta, and H. Ito: Tech. Dig. Int. Topical Meeting on Microwave Photonics, W4-5, 2004.

9) H. Nosaka, M. Nakamura, M. Ida, K. Kurishima, T. Shibata, M. Tokumitsu, and M. Muraguchi: Microwave Symposium Digest, 2004 IEEE MTT-S International Volume 1 (2004) 101.

10) M. Tanaka, T. Kondo, T. Kawamoto, Y. Kamiya, A. Fujimaki, H. Hayakawa, N. Nakajima, Y.Yamanashi, A. Akimoto, N. Yoshikawa, H. Terai, Y. Hashimoto, and S. Yorozu: IEEE Trans. Appl. Supercond. (2005) in print.

11) S. Yorozu, Y. Hashimoto, Y. Kameda, H. Terai, A. Fujimaki, and N. Yoshikawa: Proc. IEEE Workshop on High Performance Switching and Routing (IEEE, Piscataway, NJ, USA, 2004) p. 20.

\section{レーザーワード}

テラヘルツフォトニクス (terahertz photonics)

テラヘルツ周波数带の様々な機能を創製し，またその 信号を利用する光エレクトロニクス分野の総称. 光ファ イバ通信における，情報伝達容量は，超短パルスを用い ることで(光時分割多重方式)，チャネルあたり毎秒テラ ビットを越える能力が実現されている。また，フォトミ
キシング技術を用いた， $120 \mathrm{GHz}(10 \mathrm{Gpbs})$ 無線通信の フィールド実験が開催されており，光エレクトロニクス におけるテラヘルツ信号の利用が急速に開拓されつつあ る.

(斗内 政吉) 